\title{
Compressive and Flexural Strengths of Concrete Containing Ground Palm Kernel Shells as Partial Replacement of Cement
}

\author{
E. A. Armah ${ }^{1,2^{*}}$, H. A. Koffi ${ }^{1}$, J. K. A. Amuzu ${ }^{1}$ \\ ${ }^{1}$ Department of Physics, University of Ghana, Legon, LG 63, Accra, Ghana \\ ${ }^{2}$ Foundation Department, Lancaster University Ghana, P. O. Box CT 9823, Cantonments, Accra, Ghana \\ * Corresponding author email: akweteyniiabekah@gmail.com
}

Received: 27 February 2020 / Revised: 05 April 2020 / Accepted: 18 April 2020 / Published: 03 May 2020

\begin{abstract}
This study explore the possibility of using waste ground palm kernel (GPK) shells as partial replacement of cement in concrete using mechanical destructive method has been studied. The palm kernel shells were in two forms: the GPK ordinary shells and shells subjected to incomplete combustion (i.e. the GPK "fuel" shells). In the preparation of the concrete specimens the mix ratio was 1: 2: 4 (cement: sand: stone) by weight and the replacement percentage was $0 \%, 20 \%, 30 \%, 40 \%, 50 \%$ and $60 \%$ respectively. Concrete specimen were molded in both cubic and cylindrical form and its impact on the mechanical properties such as workability, compressive strength and flexural strength using destructive test method were studied. The cubic specimen were tested at 7, 28 and 60 days whiles the cylindrical specimen were tested at 7 and 28 days. Results of physical and chemical analyses suggest that GPK "fuel" shells have acceptable cementitious properties whiles GPK ordinary shells does not. Generally, the compressive and flexural strengths of concrete containing GPK shells decrease as the replacement percentage increases. However, the values of these properties increase as the period of curing increases. The optimum level of GPK shells replacement is $20 \%$ for the ordinary shells and $30 \%$ for the "fuel" shells considering compressive strength at 28 days for the cubic samples. For the flexural strength on the cylindrical specimen, up to $60 \%$ replacement of cement by GPK shells cured for 28 days has acceptable flexural strength. In spite of the findings that the GPK ordinary shells do not have cementitious properties, the mechanical properties on such concretes can be used in low strength constructions as pavements, walk ways and non structural domestic work at a lower cost than using cement.
\end{abstract}

Keywords: Cement, Compressive Strength, Concrete, Flexural Strength, Ground Palm Kernel Shells, Partial Replacement

\section{Introduction}

Concrete is the most widely used construction material and one of the most durable. It provides superior fire resistance compared with wood or steel and can gain strength with time [1]. The high and increasing cost of cement as demand increases has greatly slowed down the development of shelter and other infrastructural facilities in most developing countries. Also, the production of concrete has environmental pollution and degradation concerns. With regard to the numerous problems associated with concrete consumption, two solutions adopted so far are either the complete or partial substitution of aggregates (sand and stone) or a reduction in cement use. A reduction in cement use can only be achieved by the partial substitution or blending of cement with supplementary materials. The supplementary materials studied are mostly industrial by-products classified as industrial waste (inorganic) and naturally occurring materials classified as agro-based (organic) waste [2].

\section{Copyright (C) 2020. The Author(s). Published by AIJR Publisher.}

This is an open access article under Creative Commons Attribution-NonCommercial 4.0 International (CC BY-NC 4.0) license, which permits any non-commercial use, distribution, adaptation, and reproduction in any medium, as long as the original work is properly cited. 
Burning of agricultural wastes as a means of disposal contributes to environmental degradation and can be reduced by utilizing the materials for other purposes such as construction materials. Utilization of such wastes as cement replacement materials may reduce the cost of concrete production, alleviate the increasing challenges of scarcity and also minimize the negative environmental effects with disposal of these wastes [3]. Many researchers have studied the use of agro-waste ashes including groundnut shell ash [4], wood ash [5], corn cob ash [6], coconut shell ash [7, 8] and egg shell powder [8] as constituents in concrete production.

In the production of palm oil and palm kernel oil from bunches of palm fruits, the waste products generated are empty fruit bunches, palm fruit fibers, palm kernel shells, decanter cake and palm oil mill effluent. These are usually used as a fuel for boilers in palm oil mills, blacksmith factories and as substitute or supplements for firewood in cooking locally. The aforementioned activities produce large amounts of ash as wastes which are sometimes graded into kernel shell waste, fruit fiber waste and gel waste. The residue of the combined wastes termed palm oil fuel ash (POFA) has been studied extensively. The burnt waste from only the shells usually used at the blacksmith factories is termed palm kernel shell ash (PKSA) [3, 9].

During recent decade, many researchers have taken the initiative to develop sustainable construction material by utilizing the palm oil industrial wastes such as POFA and PKSA. With reference to POFA, Subramani and Anbuchezian [10] demonstrated that POFA prepare by partial replacement of cement concrete results in variation of compressive and tensile strengths. However, the optimum strength was at $12.5 \%$ slightly higher than the control. In studying the strength of concrete using POFA as partial replacement of cement, Priya and Durga [11] reported that the optimum percentage replacement of POFA was 15\%. Compressive, splitting tensile and flexural strengths increases as the percentage of the POFA increases and were also higher than those of normal OPC concrete. In the work of Premalatha et al [12], results show that, replacement of cement by POFA in concrete causes strength variation. However, the POFA in concrete shows high strength compare to conventional concrete with the $20 \%$ specimens being the optimum level of replacement. Oyejobi et al [3] discovered that the workability of the concrete decreased as the POFA content increased and compressive strength increased with curing age but decreased with increasing percentage of POFA. Sooraj [13] reports that strengths increases as the percentage of the POFA increases from $0 \%$ to $10 \%$. However, for $20 \%$, the tensile-strength development was the same as the control, but when increased to $30 \%$, strength starts decreasing.

Now considering PKSA, Al-Majeed et al [14] reports that, partial replacement of cement with PKSA in mortar results in decreasing compressive strength and increasing absorption. Investigation by Fadele and Ata [15] reveal the need to adjust the water/cement ratio as the PKSA content in the mix increases at each replacement level in order to produce workability and to enhance the compaction of the concrete. Their results showed that, 5\% PKSA content met structural concrete works requiring $25 \mathrm{MPa}$, while $15 \%$ met $20 \mathrm{MPa}$ strength requirements at 28 days. The effect of replacing OPC with PKSA by Otunyo and Azuma [16] shows a decreased in workability as the PKSA content was increased, while the setting time increased as the content increased. Compressive, flexural and split tensile strengths decreased as the PKSA content increased. Optimum cement replacement with PKSA occurs at 5\%.

The incorporation of PKSA as a partial replacement of cement in concrete has been investigated by Olowe and Adebayo [17]. The workability was found to decrease when compared to the control. Also, increase in PKSA led to a corresponding reduction in both flexural and compressive strengths. The recommended optimum replacement level was $25 \%$ for good compressive and tensile properties. The investigation by Olutoge et al [18], using PKSA as partial replacement for cement in concrete revealed that the presence of PKSA increases the water absorption and setting time of concrete. The $10 \%$ PKSA concrete with compressive strength of $22.80 \mathrm{~N} / \mathrm{mm}^{2}$ meets the minimum required strength at 28 days. In the research work of 
Armah et al., J. Mod. Mater.; Vol. 7, Issue 1, pp: 7-16, 2020

Mbadike and Osadebe [19], the use of PKSA as partial replacement for cement in concrete demonstrates that, the workability increases with the increase in the percentage replacement of cement. The result shows that the incorporation of PKSA in the production of concrete reduces the strength of concrete produced and the replacement cannot exceed $40 \%$.

The abundance of palm kernel shells in Ghana has compelled the investigation of the utilization of these materials as supplementary materials for concrete in the built industry. Since the ash which is the residue of the waste after burning is only about $5 \%$, the need to investigate the raw waste without being burnt into ash has become necessary in order to increase the quantity of the material for the partial replacement of cement. The objective of this study is to investigate the utilization of palm kernel shells for partial replacement of cement in concrete based on mechanical properties such as compressive strength and flexural strength. The porosity, permeability and the strength of concrete containing these shells have been measured.

\section{Materials and Methods}

The normal materials used in making of concrete being Portland limestone cement, coarse aggregates and fine aggregate were employed in this research with ground palm kernel shells substituting for cement. The cement used was the locally made Diamond Brand Ordinary Portland Cement (OPC). The coarse aggregate used has irregular shape and wide variety of sizes between $9 \mathrm{~mm}$ and $64 \mathrm{~mm}$ and the size of the fine aggregate is less than $4 \mathrm{~mm}$. The water used was obtained from the source that is available for everyday use in houses (i.e., tap water).

The palm kernel shells were collected from a palm kernel mill and were washed and dried at ambient temperature of an average of $30^{\circ} \mathrm{C}$ for one week. Some of the shells were subjected to incomplete combustion using the methodology for the production of charcoal: they were covered with leaves and soil, set alight and allowed to smoulder for about 3 days. As a result of this process, the shells turned black, lightweight and brittle as shown in Figure 1.

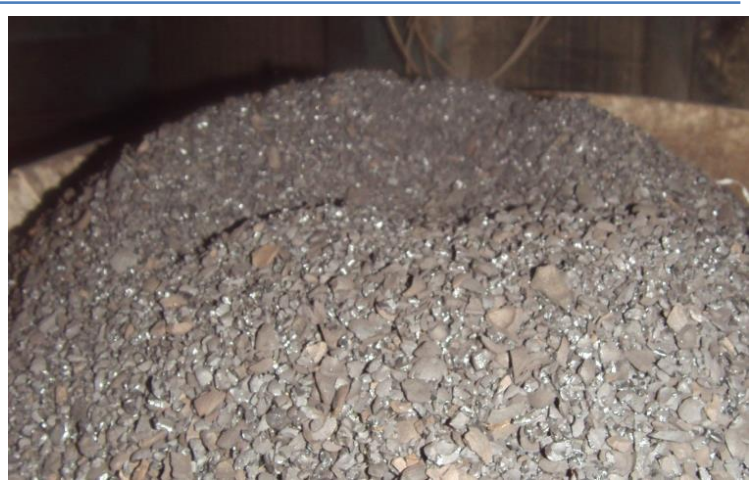

Figure 1: The black, lightweight and brittle Palm Kernel "fuel" shells

In this work, these shells are referred to, as "fuel" shells and the shells not subjected to this process of incomplete combustion are the ordinary shells. The "fuel" shells and the ordinary shells were ground to fine powder in a grinding mill as shown in Figure 2. The ground fine powders were termed GPK "fuel" shells and GPK ordinary shells respectively.

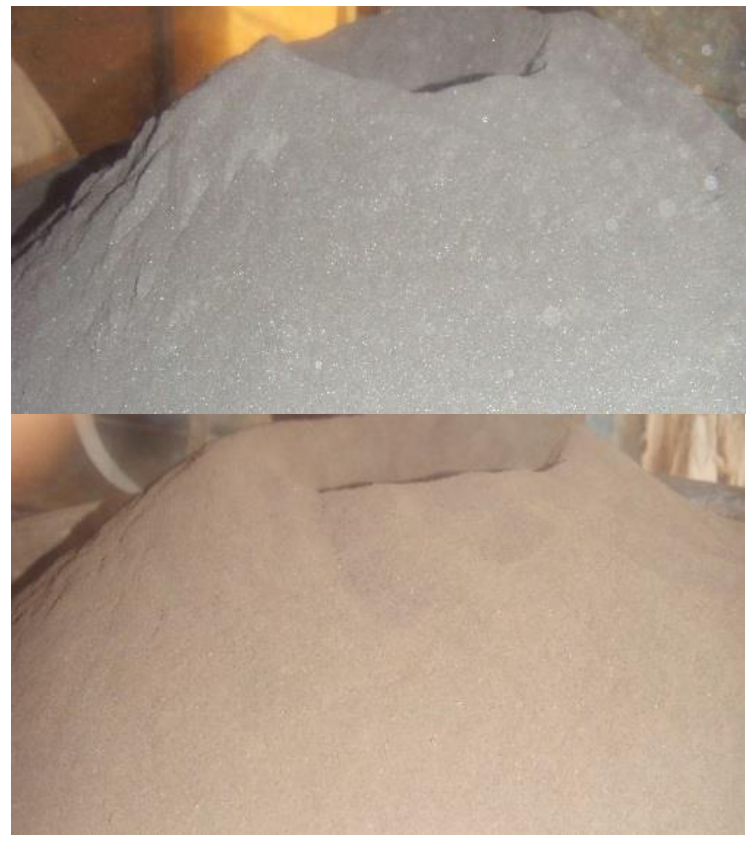

Figure 2: Ground Palm Kernel "fuel" shells (top) and ordinary shells (bottom)

\subsection{Specimen Preparation}

\subsubsection{Mix Design}

Mix design is the processes of selecting suitable ingredients of concrete and determining their relative quantities, with the purpose of producing an economical concrete that has certain minimum properties, notably workability, strength, consistency and durability. It should be pointed 
out that the mix design of concrete is frequently done by trial and error. Hence, mix design of concrete is an art, not a science. To obtain a satisfactory mix, one must check the estimated proportions of the mix by making trial mixes and, if necessary, make appropriate adjustments to the proportions until a satisfactory mix has been obtained [20,21]. Acceptable concrete usually has proportions within the ranges, by volume [22], of

- cement $7 \%$ to $17 \%$

- water $15 \%$ to $20 \%$

- aggregate $63 \%$ to $78 \%$

The requirements for mix design include quality (strength and durability), workability and economy. In the preparation of the concrete specimens a mixing ratio of 1: 2: 4 (cement: sand: stone) by weight was adopted in order to lower cost. The weight of the aggregates (fine and coarse) was $2.67 \mathrm{~kg}$ and $5.34 \mathrm{~kg}$ for the cubic and $4.0 \mathrm{~kg}$ and $8.0 \mathrm{~kg}$ for the cylindrical. The replacement percentages were $0 \%, 20 \%, 30 \%$, $40 \%, 50 \%$ and $60 \%$ respectively. In all a total of 135 cubes and 66 cylinders of concrete were prepared in accordance with BS 1881: Part 127 [23]. The dimension of the cubic concrete specimens was $150 \times 150 \times 150 \mathrm{~mm}$ and that of the cylindrical specimens were $110 \mathrm{~mm}$ and 500 $\mathrm{mm}$ diameter and length respectively.

\subsubsection{Water-To-Cement Ratio (Workability)}

The workability of concrete contains two aspects, consistency and cohesiveness. To obtain the same level of these properties in all the mixes with respect to the percentage replacement of the palm kernel shell and the control, a reasonable $\mathrm{W} / \mathrm{C}$ mix ratio was maintained for the entire specimen. It is important to note that, water content is regarded as the most important factor influencing the workability of concrete. If the water content is too small, the concrete will become too dry to mix and place. Increasing the amount of water will increase the amount of water for lubrication and hence improve the fluidity and make it easy to be compacted. However, too much water will reduce cohesiveness causing segregation and bleeding, and also reducing concrete strength [21].

The water-to-cement ratio is simply the mass of water divided by the mass of cementitious material and is the single most important factor affecting concrete strength. The amount of water required was determined using the specified water to cement ratio

$$
W_{w}=W_{c} \times \alpha
$$

where $W_{W}$ is weight of water, $W_{C}$ weight of cement and $a$ is the water-to-cement ratio $w / c$ [24]. Trial mixes based on the above considerations were made and used to determine the final proportions for the mix designs which gave the water-to-cement ratio as 0.8 . In the trails, there was a gradual increased in the demand of water as the GPK shells percentage content was increased. For both (GPK ordinary and "fuel" shells) mixes, the workability of the fresh concrete decreases as the percentage replacement of the palm kernel shell content increases. However, the workability of the "fuel" shells is better than the ordinary shells based on their porosity and permeability properties.

Table 1: Cubic Concrete Test Specimen Mix Design

\begin{tabular}{|c|c|c|c|c|c|c|}
\hline \multirow{2}{*}{$\begin{array}{l}\text { Materials } \\
\text { Weight of Cement } \\
(\mathrm{kg})\end{array}$} & \multicolumn{6}{|c|}{ Replacement Ratio } \\
\hline & 1.33 & 1.07 & 0.93 & 0.80 & 0.67 & 0.53 \\
\hline $\begin{array}{l}\text { Weight of GPK } \\
\text { Shells }(\mathrm{kg})\end{array}$ & 0.00 & 0.27 & 0.40 & 0.53 & 0.67 & 0.80 \\
\hline $\begin{array}{l}\text { Weight of Fine } \\
\text { Aggregate }(\mathrm{kg})\end{array}$ & 2.67 & 2.67 & 2.67 & 2.67 & 2.67 & 2.67 \\
\hline $\begin{array}{l}\text { Weight of Coarse } \\
\text { Aggregate }(\mathrm{kg})\end{array}$ & 5.33 & 5.33 & 5.33 & 5.33 & 5.33 & 5.33 \\
\hline $\begin{array}{l}\text { Weight of Water } \\
(\mathrm{kg})\end{array}$ & 1.07 & 1.07 & 1.07 & 1.07 & 1.07 & 1.07 \\
\hline $\begin{array}{l}\text { GPK Shells } \\
\text { Percentage } \\
\text { Replacement of } \\
\text { Cement }(\%)\end{array}$ & 0 & 20 & 30 & 40 & 50 & 60 \\
\hline
\end{tabular}

Table 2: Cylindrical Concrete Test Specimen Mix Design

\begin{tabular}{|c|c|c|c|c|c|c|}
\hline \multirow{2}{*}{$\begin{array}{l}\text { Materials } \\
\text { Weight of Cement } \\
(\mathrm{kg})\end{array}$} & \multicolumn{6}{|c|}{ Replacement Ratio } \\
\hline & 2.00 & 1.60 & 1.40 & 1.20 & 1.00 & 0.80 \\
\hline $\begin{array}{l}\text { Weight of GPK } \\
\text { Shells (kg) }\end{array}$ & 0.00 & 0.40 & 0.60 & 0.80 & 1.00 & 1.20 \\
\hline $\begin{array}{l}\text { Weight of Fine } \\
\text { Aggregate }(\mathrm{kg})\end{array}$ & 4.00 & 4.00 & 4.00 & 4.00 & 4.00 & 4.00 \\
\hline $\begin{array}{l}\text { Weight of Coarse } \\
\text { Aggregate }(\mathrm{kg})\end{array}$ & 8.00 & 8.00 & 8.00 & 8.00 & 8.00 & 8.00 \\
\hline $\begin{array}{l}\text { Weight of Water } \\
(\mathrm{kg})\end{array}$ & 1.60 & 1.60 & 1.60 & 1.60 & 1.60 & 1.60 \\
\hline $\begin{array}{l}\text { GPK Shells } \\
\text { Percentage } \\
\text { Replacement of } \\
\text { Cement }(\%)\end{array}$ & 0 & 20 & 30 & 40 & 50 & 60 \\
\hline
\end{tabular}

\subsubsection{Moulding of Test Specimen}

Regardless of the sophistication of the mix design procedures used and other considerations, such as 
cost, a concrete mixture that cannot be placed easily or compacted fully is not likely to yield the expected strength and durability characteristics [21]. The various components (sand, stone and cement and/or ground palm kernel shells respectively) were thoroughly mixed on a platform. Water was then measured and poured on the dry mixture. The concrete mix was turned over again and again until a homogeneous mix was achieved. The mix was turned over again, until it appears uniform in colour and consistency as described by [20]. The concrete mix was placed in moulds and compacted. Additional compaction was achieved for the cubic moulds by means of a vibrating compactor. The required surface appearance of the specimens was achieved by leveling and smoothing to the level of the mould.

\subsubsection{Curing of Specimen}

In order to obtain good concrete, curing is necessary in a suitable environment during the early stages of hardening. The concrete specimens were kept covered with asbestos sheets and jute sacks on the day of moulding. Three days after moulding, the specimens were demoulded and immersed in water for the remaining days of the curing period. The period of curing required in practice cannot be prescribed in a simple manner. This depends on the type of cement used, mix proportions, required strength, size and shape of the concrete mass, weather, and future exposure conditions $[20,25]$. The type of cement used in this work which is of the Type I (general-purpose cement) reaches its design strength in 28 days according to ASTM CI50 [26]. However, some types reach their design strength in 45 days, some at an early age, usually seven days or less, others in 90 days and 60 days respectively [27]. For these reasons, the curing periods used were 7 days, 28 days and 60 days for the cubes and 7 days and 28 days for the cylinders.

\subsection{Test Procedure}

\subsubsection{Physical and Chemical Tests of Cement and Ground Palm Kernel Shells}

Physical analysis were performed on the Portland cement and the ground palm kernel shells at the quality control laboratory of the Ghana Cement Company (Ghacem) Ltd at Tema and the chemical analysis at laboratories of the Ghana Standards Authority and the Ghana Atomic Energy Commission. The physical properties determined were the fineness (sieving and air permeability or Blaine methods), porosity, permeability and true density using the procedures in test standard EN 196 [28]. The chemical test determines the elemental constituents. This is because the amount of silica, alumina and iron determines the quality of a pozzolanic material.

\subsubsection{Fineness Test: Air Permeability (or Blaine) Method}

The air permeability method measures the specific surface area of the substance and compares it to the area of a reference sample. This method is used primarily to check the consistency of the grinding process. The test was carried out using the standards for testing Portland cement. This standard, ASTM C204-07 [29] requires the density and porosity of the materials to be determined and used in the calibration of the apparatus. In this test, a density of $3.5 \mathrm{~g} / \mathrm{cm}^{3}$ and porosity of 0.5 being that of cement was used.

\subsubsection{Measurement of Porosity and Permeability}

In performing this experiment, a small square piece of pantyhose of side $20 \mathrm{~cm}$ was cut and folded into half. The pantyhose was placed over the mouth of a bottle (whose bottom has been cut off) and secured with rubber band. The bottle was filled with dry sample and the weight of sample and bottle was recorded. The bottle was then clamp on a ring stand. A $200 \mathrm{ml}$ of water was slowly added to the sample. A beaker was positioned under the neck of the bottle to collect the water sipping through the sample. The time taken for as much water as possible to sip through the sample was recorded. The mass of the wet sample in the bottle was also measured. The porosity of the sample was determined using the relationship:

$$
\emptyset=\frac{W_{3}-W_{2}}{W_{2}-W_{1}}
$$

where $\phi$ is porosity, $W_{1}$ is the weight of empty bottle, $W_{2}$ is the weight of bottle with dry sample and $W_{3}$ is the weight of bottle with wet sample. 
The permeability, $k, \mathrm{cms}^{-1}$ was also calculated using the expression,

$$
k=\frac{V_{w}}{t}
$$

where $V_{w}$ is the volume of water that sip through the sample in time, $t$.

\subsubsection{Measurement of Density}

In an attempt to determine the true or particle density of cement together with our materials (ground ordinary palm kernel shells and "fuel shells"), the same method was used for easy comparison according to the standard ASTM C188-09 [30] which deals with the determination of density of cement. For the bulk density, a graduated cylinder was first weighed and a quantity of the powder material was poured into the cylinder. The level of the material in the cylinder was noted and weight of the cylinder also taken and recorded. The ratio of the difference in masses (final mass of cylinder with material-empty cylinder mass) and the volume of cylinder with material was used to determine the density.

\subsubsection{Mechanical Tests on the Concrete}

To evaluate the mechanical properties of the concrete, the specimens were tested for compressive strength (cubic specimens) and flexural strength (cylindrical specimens) at laboratories of the Ghana Standards Authority.

\subsubsection{Determination of Compressive Strength}

To determine the compressive strength, the test was carried out using the 50-C54A Control Compression Testing Machine. Before placing the cube in the machine, it was ensured that all bearing surfaces including the platens and the cube were free of any extraneous material. The compressive tests were carried out in accordance with test standard BS 1881 Part 116 [23]. The load or force was applied automatically at a preset nominal rate of $0.3 \mathrm{~N} / \mathrm{mm}^{2}$.s until the concrete specimen was crushed. The force to crush the specimen was recorded. The compressive machine has a maximum load capacity of $2000 \mathrm{KN}$ and a minimum load of $5 \mathrm{KN}$. The area of crushing of the platen piston is $226.93 \mathrm{~cm}^{3}$ and has loading rate ranging from 0.2 to $0.4 \mathrm{~N} / \mathrm{mm}^{2}$.s. In all a total of 135 cubic concrete specimens were crushed.

\subsubsection{Determination of Flexural Strength}

Similarly, in the determination of the flexural strength, the test was carried out using the model 53-C0004/A Flexure Machine in accordance with test standard ISO 4013(E) [31]. The flexural testing machine consists of two arm (rollers) on which the cylindrical specimen is placed. A third arm or roller is lowered onto the specimen and that it is at the midpoint of the line joining the two lower arms. This is the centre-point loading arrangement. The rollers were first cleaned and the distance between the two lower rollers were set at $40 \mathrm{~cm}$. The load was applied steadily until the specimen was at the point of failing (automatically fractured by the machine). The deflection on the measuring ring of the flexural machine (i.e. dial reading in $\mathrm{mm}$ ) was recorded. The recorded value was compared with the standardized index calibrators chat to determine the breaking load and calculate the flexural strength. In all a total of 66 cylindrical concrete specimens were tested. Figures 3 (a) and (b) show the mechanical test to determine the compressive and flexural strengths respectively.

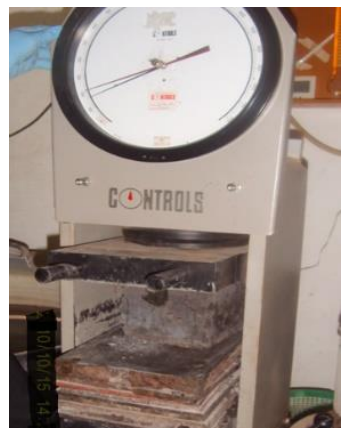

(a)

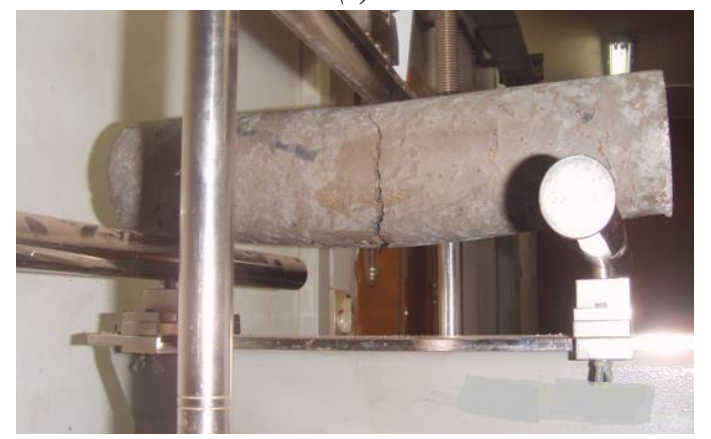

(b)

Figure 3: Testing for Compressive (a) and Flexural (b) strengths of Concrete Specimens 


\section{Results and Discussion}

\subsection{Physical Analyses of Cement and GPK Shells}

Table 3 shows the results of the physical properties tests determined for the cement and the GPK shells. For the fineness test using the sieving method, the amount of cement (being the control) retained by the sieve was far less than that retained by the GPK shells. This gives the control superior percentage fineness over the GPK shells. However, the GPK "fuel" shells are finer than the GPK ordinary shells. Using the air permeability or Blaine method, the specific surface of the GPK "fuel" shells was observed to be higher than that of the control but close and fall within a typical ordinary Portland cement specific surface of between 300 to $400 \mathrm{~m}^{2} / \mathrm{kg}$ [32]. It was found that GPK "fuel" shells is finer than cement, and this may be as a result of the fact that the shape of the particles in the GPK "fuel" shells were observed to be elongated. This line of thinking is similar to that reported by [33] when glass powder was used as partial replacement for cement. However, the fineness value of the GPK ordinary shells fell far below the typical ordinary Portland cement specific surface.

Table 3: Physical Properties of Cement, GPK "Fuel" Shells and Ordinary Shells

\begin{tabular}{|l|r|r|r|}
\hline \multirow{2}{*}{ Physical Properties } & \multicolumn{3}{|c|}{ Sample } \\
\cline { 2 - 4 } & Cement & $\begin{array}{c}\text { Ordinary } \\
\text { Shells }\end{array}$ & $\begin{array}{c}\text { Fuel } \\
\text { Shells }\end{array}$ \\
\hline Particle Fineness $(\%)$ & 96.02 & 58.55 & 69.95 \\
\hline Blaine Fineness $\left(\mathrm{m}^{2} / \mathrm{kg}\right)$ & 328.31 & 112.61 & 364.89 \\
\hline Porosity & 0.49 & 0.60 & 0.32 \\
\hline Permeability $\left(\mathrm{ml} / \mathrm{min}^{2}\right)$ & 0.09 & 0.19 & 0.06 \\
\hline True Density $\left(\mathrm{kg} / \mathrm{m}^{3}\right)$ & 2974.44 & 1370.03 & 1614.02 \\
\hline $\begin{array}{l}\text { Compact Bulk Density } \\
\left(\mathrm{kg} / \mathrm{m}^{3}\right)\end{array}$ & 1467.00 & 811.00 & 841.00 \\
\hline $\begin{array}{l}\text { Loose Bulk Density } \\
\left(\mathrm{kg} / \mathrm{m}^{3}\right)\end{array}$ & 1037.00 & 670.00 & 700.00 \\
\hline
\end{tabular}

The porosity test result shows that the control conforms to the standard porosity of OPC which is 0.5 .

The GPK "fuel" shells was less porous whiles the GPK ordinary shells the most porous. Thus, the GPK ordinary shells absorbed more water than cement and the GPK "fuel" shells. The permeability results also reveal similar trend were the GPK ordinary shells are more permeable than the control and the GPK "fuel" shells. This trend seems to agree with the fineness test performed by the air permeability or Blaine method confirming the elongated nature of the GPK "fuel" shells. The true density of the control was found to be close to the standard density of OPC which is $3500 \mathrm{~kg} / \mathrm{m}^{3}$. That of the ordinary and "fuel" shells was found to fall far below this value.

\subsection{Chemical Analysis of Cement and GPK Shells}

The results of chemical analysis are presented in Table 4. Portland cement is composed of four major oxides which are lime $(\mathrm{CaO})$, silica $\left(\mathrm{SiO}_{2}\right)$, alumina $\left(\mathrm{Al}_{2} \mathrm{O}_{3}\right)$, and iron $\left(\mathrm{Fe}_{2} \mathrm{O}_{3}\right)$ which sum up to almost $95 \%$ and small amount of magnesia $(\mathrm{MgO})$, alkalis $\left(\mathrm{Na}_{2} \mathrm{O}\right.$ and $\left.\mathrm{K}_{2} \mathrm{O}\right)$, and sulfuric anhydrite $\left(\mathrm{SO}_{3}\right) \quad[32,34,35]$. However, the standard minimum specification required for pozzolan to be use as mineral admixture in Portland cement concrete is $50 \%$ according to standard ASTM C618 [36]. From the results, the total amount of the major oxides in the control sample was $93.32 \%$ (close to the standard of 95\%), whiles the GPK "fuel" shells and ordinary shells is $66.33 \%$ and $41.29 \%$ respectively. This means that the GPK "fuel" shells contain more than $50 \%$ of the four major oxides and have demonstrated its ability to be used as cementitious materials by meeting the chemical requirements as pozzolan with the ordinary shells slightly below.

Table 4: Chemical composition of Cement, GPK "Fuel" Shells and Ordinary Shells

\begin{tabular}{|l|l|r|r|r|}
\hline \multirow{2}{*}{ Oxide } & \multirow{2}{*}{$\begin{array}{c}\text { Common } \\
\text { Name }\end{array}$} & \multicolumn{3}{|c|}{$\begin{array}{r}\text { Percentage Composition by Mass } \\
(\%)\end{array}$} \\
\cline { 3 - 5 } & & Cement & $\begin{array}{c}\text { Fuel } \\
\text { Shells }\end{array}$ & \multicolumn{1}{c|}{$\begin{array}{c}\text { Ordinary } \\
\text { Shells }\end{array}$} \\
\hline $\mathrm{CaO}$ & Lime & 63.19 & 7.28 & 1.64 \\
\hline $\mathrm{SiO}_{2}$ & Silica & 15.61 & 9.24 & 3.31 \\
\hline $\mathrm{Al}_{2} \mathrm{O}_{3}$ & Alumina & 10.17 & 14.68 & 14.46 \\
\hline & Ferric & & & \\
$\mathrm{Fe}_{2} \mathrm{O}_{3}$ & Oxide & 4.35 & 35.13 & 21.88 \\
\hline $\mathrm{MgO}_{2}$ & Magnesia & 4.88 & 11.58 & 28.93 \\
\hline $\mathrm{K}_{2} \mathrm{O}$ & Alkalis & 0.54 & 11.39 & 20.54 \\
\hline $\mathrm{Na}_{2} \mathrm{O}$ & Alkalis & 0.11 & 5.04 & 5.61 \\
\hline
\end{tabular}

\subsection{Mechanical Tests Results on the Concrete Specimen}

\subsubsection{Compressive Strength of Cubic Specimens}

The results of the crushing test of the cubic specimens for the determination of the 
Compressive and Flexural Strengths of Concrete Containing Ground Palm Kernel Shells as Partial Replacement of Cement

compressive strengths at various GPK shells replacement percentages including the control ( $0 \%$ replacement) being the normal concrete are shown in Table 5. The 28 days result was used for the analyses because, it is known that, between $80 \%$ and $95 \%$ of the final and maximum strength of cement concrete is achieved in 28 days. Indeed, as a structural material, the compressive strength at an age of 28 days is the main design index for concrete.

Table 5: Compressive Strength for Concrete containing GPK Ordinary Shells and "Fuel Shells"

\begin{tabular}{|c|c|c|c|c|c|c|}
\hline \multirow{3}{*}{$\begin{array}{c}\text { Replacement } \\
\text { Percentages }\end{array}$} & \multicolumn{6}{|c|}{ Compressive Strength (MPa) } \\
\hline & \multicolumn{3}{|c|}{ GPK ordinary shells } & \multicolumn{3}{|c|}{ GPK "fuel" shells } \\
\hline & $\begin{array}{c}7 \\
\text { days }\end{array}$ & $\begin{array}{c}28 \\
\text { days }\end{array}$ & $\begin{array}{c}60 \\
\text { days }\end{array}$ & $\begin{array}{c}7 \\
\text { days }\end{array}$ & $\begin{array}{c}28 \\
\text { days }\end{array}$ & $\begin{array}{c}60 \\
\text { days }\end{array}$ \\
\hline 0 & 13.93 & 24.74 & 29.33 & 13.93 & 24.74 & 29.33 \\
\hline 20 & 8.74 & 15.41 & 18.96 & 10.67 & 17.78 & 21.04 \\
\hline 30 & 6.96 & 12.15 & 15.11 & 8.30 & 14.81 & 17.48 \\
\hline 40 & 5.48 & 7.11 & 9.48 & 5.63 & 8.15 & 11.26 \\
\hline 50 & 3.11 & 5.04 & 6.67 & 4.00 & 6.52 & 8.44 \\
\hline 60 & 0.89 & 1.93 & 2.81 & 2.30 & 4.59 & 5.48 \\
\hline
\end{tabular}

The compressive strength was found to decrease with increasing percentage replacement for a given curing period. Also, for a given replacement percentage, the strength increases with increasing curing period. This is due to the fact that, when supplementary cementitious materials are used in concrete as partial replacement of cement, the strength generally decreases $[32,36]$. Additionally, our results are also in good agreement with the findings of Otunyo and Azuma [16], Oyejobi et al [3] and Sooraj [13]. The results show that, $20 \%$ or less replacement of cement by GPK ordinary shells and up to $30 \%$ by the GPK "fuel shells" concrete specimens meet the standard compressive strength requirement for lightweight applications. This is because, typically, the compressive strength required for domestic work, footpaths and driveways is between $15 \mathrm{MPa}$ to 25 MPa [22]. This satisfy the design that, the average compressive strength of concrete at 28 days in relation to water-to-cementitious ratio of 0.80 for the replacement of Portland cement with pozzolans at $10-30 \%$ is usually $15 \mathrm{MPa}$ [24].

Generally, the specimens containing the "fuel" shells have higher compressive strength than those containing the ordinary shells as can be observed from Figure 4. This could be attributed to the better chemical and physical pozzolanic properties of the "fuel" shells compared to the ordinary shells.

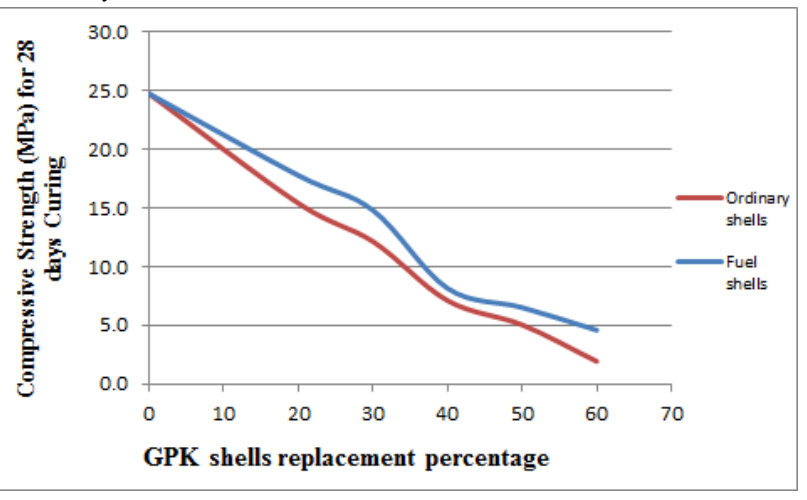

Figure 4: Compressive strength of "fuel" shells samples compared to those of ordinary shells

\subsubsection{Flexural Strength of Tubular Specimens}

The results of the breaking test of the tubular specimens for the flexural strengths at various GPK shell replacement percentages are shown in Table 6.

Table 6: Flexural Strength for Concrete containing GPK Ordinary Shells and "Fuel" Shells

\begin{tabular}{|c|r|r|r|r|}
\hline \multirow{2}{*}{$\begin{array}{c}\text { Replacement } \\
\text { Percentages }\end{array}$} & \multicolumn{4}{|c|}{ Flexural Strength (MPa) } \\
\cline { 2 - 5 } & \multicolumn{1}{|c|}{ GPK ordinary shells } & \multicolumn{1}{c|}{ GPK "fuel" shells } \\
\cline { 2 - 5 } & \multicolumn{7}{|c|}{ days } & \multicolumn{2}{|c|}{ days } & 7 days & \multicolumn{1}{c|}{$\mathbf{2 8}$ days } \\
\hline 0 & 4.17 & 6.38 & 4.17 & 6.38 \\
\hline 20 & 3.36 & 4.86 & 3.36 & 5.22 \\
\hline 30 & 2.82 & 3.96 & 2.82 & 4.54 \\
\hline 40 & 2.39 & 3.36 & 2.39 & 3.75 \\
\hline 50 & 2.01 & 2.82 & 2.01 & 3.17 \\
\hline 60 & 1.69 & 2.23 & 1.69 & 2.51 \\
\hline
\end{tabular}

From the results, it was clear that, as GPK shells mix ratios are increased, the flexural strength decreased for a giving curing period. However, as the curing period was increased, the flexural strength also increased. These trends are supported by Otunyo and Azuma [16]. Typical values for flexural strength for concrete used for pavements range from $2 \mathrm{MPa}$ to $7 \mathrm{MPa}$ [37]. Fortunately, all of the flexural strength values at 28 days fall within this range. The results show clearly that, concrete containing up to $60 \%$ replacement of cement by GPK shells and cured for 28 days has acceptable flexural strength for the application in pavements. As observed with the compressive strength, the specimens containing the "fuel" shells have higher flexural strength than those containing the ordinary shells as shown in 
Armah et al., J. Mod. Mater.; Vol. 7, Issue 1, pp: 7-16, 2020

Figure 4. The variation in strength could be attributed to their particle fineness and chemical composition.

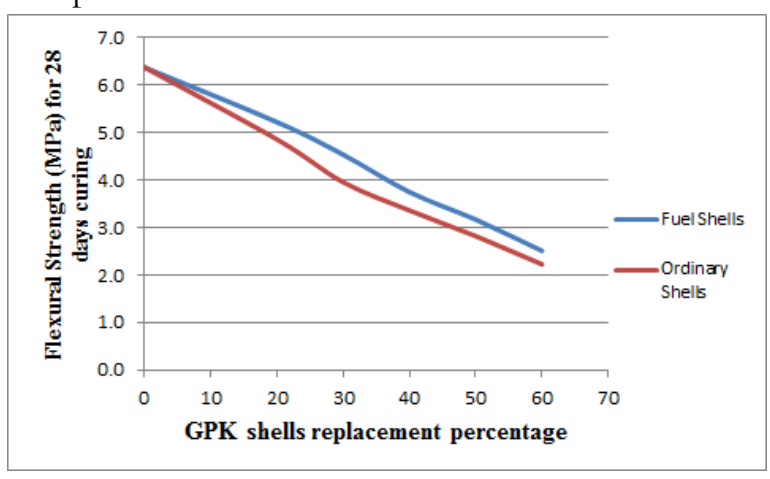

Figure 5: Flexural strength of "fuel" shells samples compared to those of ordinary shells

\section{Conclusions}

A comparative study of the properties of concrete containing GPK ordinary shells and GPK "fuel shells" as partial replacement for cement has been carried out. Results from the physical and chemical analyses imply that GPK "fuel shells" have acceptable cementitious properties by meeting the requirements as pozzolan while GKP ordinary shells do not. This finding correlates well with our results of the mechanical tests conducted on concrete in which varying amounts of cement are replaced with these GPK shells. The mechanical results show that, the compressive strength and flexural strength of the concrete specimens produced decrease as replacement percentages are increased but increase as curing periods are increased. The optimum level of GPK shells replacement is $20 \%$ for the ordinary shells and $30 \%$ for the "fuel" shells considering compressive strength at 28 days. For the flexural strength, concrete containing up to $60 \%$ replacement of cement by GPK shells has acceptable flexural strength. In spite of the finding that the GPK ordinary shells do not have cementitious properties, the mechanical properties of concrete containing these shells are such that it can be used in such low-strength construction as pavements, walk ways, and non structural domestic work. This may help reduce cement usage in concretes thereby reducing the cost of concrete production, alleviate the increasing challenges of scarcity and also minimize the negative environmental effects with disposal of such wastes.

\section{Competing Interests}

The authors declared that they don't have any conflict of interest in this publication.

\section{How to Cite this Article:}

E. Armah, H. Koffi, and J. Amuzu, "Compressive and Flexural Strengths of Concrete Containing Ground Palm Kernel Shells as Partial Replacement of Cement”, J. Mod. Mater., vol. 7, no. 1, pp. 7-16, May 2020. https://doi.org/10.21467/jmm.7.1.7-16

\section{References}

[1] J. Newman and B. S. Choo, "Advanced Concrete Technology-Concrete Properties," Elsevier Butterworth Heinemann, Great Britain, pp. 1/14-17. 2004.

[2] A. P. Adewuyi and T. Adegoke, "Exploratory Study of Periwinkle Shells as Coarse Aggregates in Concrete Works," Asian Research Publishing Network (ARPN), Journal of Applied Sciences Research, vol. 4, pp. 16781680,2008

[3] D. O. Oyejobi, T. S. Abdulkadir and A. T. Ahmed, "A Study of Partial Replacement of Cement with Palm Oil Fuel Ash in Concrete Production", International Journal of Agricultural Technology, vol. 12, no. 4, pp. $619-631$, 2015.

[4] R. I. Umasabor and J. O. Okovido, "Investigation of the Compressive Strength and Curing Duration of Binary Blend of Groundnut Shell Ash Concrete", Nigerian Journal of Environmental Sciences and Technology (NIJEST), vol 1, no. 1, pp 75-80, March 2017.

[5] A. S. A. S. Manapurath, D. B. D. M. Sebastian and D. Philip , "Partial Replacement of Cement with Wood Ash," International Journal of Science Technology \& Engineering (IJSTE), vol. 2, no. 11, pp. 666-670, May 2016.

[6] P. H. Desai, "Experimental Study on Corn Cob Ash Powder as Partial Replacement of Cement in Concrete," International Research Journal of Engineering and Technology (IRJET), vol. 5, no. 6, pp. 724 -728, June2018.

[7] V. K. Nagarajan, S. A. Devi, S. P. Manohari and M. M. Santha, "Experimental Study on Partial Replacement of Cement with Coconut Shell Ash in Concrete", International Journal of Science and Research (IJSR), vol. 3, no. 3, March 2014.

[8] M. Nivedhitha and M. Sivaraja, "Experimental Study on Partial Replacement of Cement with Coconut Shell Powder and Egg Shell Powder," International Journal of Innovative Research in Science, Engineering and Technology(IJIRSET), vol. 6, no. 5, pp. 8505-8510, May 2017. DOI:10.15680/IJIRSET.2017.0605202 8505

[9] M. S. Rani and M. Tejaanvesh, "Performance of HighStrength Concrete Using Palm Oil Fuel Ash as Partial Cement Replacement", Int. Journal of Engineering Research and Applications, vol. 5, no. 4, pp. 8-12, April 2015.

[10] T. Subramani and A. Anbuchezian, "Experimental Study of Palm Oil Fuel Ash as Cement Replacement of Concrete," International Journal of Application or 
Innovation in Engineering \& Management (IJAIEM), vol. 6, no. 3, pp. 1-5, March 2017.

[11] A. K. Priya and V. K. Durga, “ A Study on Strength of Fibre Reinforced Concrete with Palm Oil Fuel Ash as Partial Replacement of Cement", International Journal of Engineering Science and Computing, vol. 7, no.7, pp. 14257-14263, July 2017.

[12] P. Premalatha, K. R. Vinodh, L. C. Anto and R. Nithiya, "Properties of Palm Ash Concrete", International Journal of Engineering Science Invention, vol. 5, no. 8, pp. 29-32, August 2016.

[13] V. M. Sooraj, "Effect of Palm Oil Fuel Ash (POFA) on Strength Properties of Concrete", International Journal of Scientific and Research Publications, vol. 3, no. 6, pp 1-7, June 2013.

[14] E. A. Al-Majeed, D. H. Hameed and M. S. Al Mohnia, "The Effect of Palm Kernel Powder on Compressive Strength and Absorption of Portland Cement Mortar", International Journal of Civil Engineering and Technology (IJCIET), vol. 9, no. 10, pp. 213-223, October 2018.

[15] O. A, Fadele and O. Ata, "Compressive Strength of Concrete Containing Palm Kernel Shell Ash", American Journal of Engineering Research (AJER), vol. 5, no.12, pp. 32-36, 2016.

[16] A. W. Otunyo and A. G. Azuma, "Investigation of the effect of Palm Bunch Ash (PBA) on concrete properties", Journal of Multidisciplinary Engineering Science Studies (JMESS), vol. 2, no. 11, pp. 1141-1146, November 2016.

[17] K. O. Olowe and V. B. Adebayo, "Investigation on Palm Kernel Ash as Partial Cement Replacement in High Strength Concrete", SSRG International Journal of Civil Engineering (SSRG-IJCE), vol. 2, no. 4, pp. 48-55, April 2015.

[18] F. A. Olutoge, H. A. Quadri and O. S. Olafusi, "Investigation of the Strength Properties of Palm Kernel Shell Ash Concrete", ETASR - Engineering, Technology \& Applied Science Research, vol. 2, no. 6, pp. 315-319, 2012.

[19] E. M. Mbadike and N. N. Osadebe, "The Use of Palm Kernel Hush Ash in Concrete Production, Journal of Engineering and Applied Sciences, vol. 8, no. 1, pp. 6367, 2012.

[20] A. M. Neville, "Fresh concrete", Properties of concrete, Fifth Edition, Pearson Education Limited, England, pp. 698, 2011

[21] L. Zongjin, "Fresh Concrete", Advanced Concrete Technology, John Wiley \& Sons, Inc., Hoboken, New Jersey, pp. 107-114, 2011.

[22] International Atomic Energy Agency (IAEA), "General Knowledge", Guidebook on Nondestructive Testing of Concrete Structures, Training Course Series No. 17, Vienna, Australia, pp. 7, September 2002.

[23] BS 1881 Part 116, "Method for Determination of Compressive Strength of Concrete Cubes", British Standards Institute, London. 1983.

[24] E. G. Nawy, Concrete Construction Engineering Handbook, $2^{\text {nd }}$ ed, CRC Press, USA, pp. 11, 2008.

[25] J. Newman and B. S. Choo, "Fresh concrete", Advanced Concrete Technology-Concrete Properties, Elsevier Butterworth Heinemann, Great Britain, pp. 1/4-5, 2003.

[26] ASTM CI50, "Standard Specifications for Portland Cement", American Society for Testing and Materials, ASTM International, West Conshohocken, PA, USA, 2003..

[27] F. S. Merritt and J. T. Ricketts, "Building Materials", Building Design and Construction Handbook, Sixth Edition, McGraw-Hill, New York, pp. 4.3, 2001.

[28] EN 196, Part 6. "Methods of Testing CementDetermination of Fineness", European Standard, USA. 1989.

[29] ASTM C204- 07 "Standard Test Methods for Fineness of Hydraulic Cement by Air-Permeability Apparatus", American Society for Testing and Materials, ASTM International, West Conshohocken, PA, USA, 2003.

[30] ASTM C188 - 09 "Standard Test Method for Density of Hydraulic Cement", American Society for Testing and Materials, ASTM International, West Conshohocken, PA, USA, 2003.

[31] ISO 4013-1978(E), "Concrete-Determination of Flexural Strength of Test Specimen”, International Standardization Organization, Switzerland, 1978.

[32] A. M. Neville, "Cementitious materials of different types", Properties of concrete, Fifth Edition, Pearson Education Limited, England, pp. 278, 2011.

[33] N. Neithalath and N. Schwarz, "Properties of Cast-InPlace Concrete and Precast Concrete Blocks Incorporating Waste Glass Powder", The Open Construction and Building Technology Journal, vol. 3, pp. 42-51, 2009.

[34] G. V. O. Hendrik, "Background Facts and Issues Concerning Cement and Cement Data", Open-File Report 2005-1152, U.S. Department of the Interior, U.S. Geological Survey, U.S., pp. 13-14, 2005.

[35] R. K., Kirby, and H. M. Kanare, "Standard Reference Materials", Portland Cement Chemical Composition Standards (Blending, Packaging, And Testing), U.S. Department of Commerce, National Bureau of Standard Special Publication 260-110, Washington pp. 22, 1988.

[36] ASTM C618, "Standard Specification for Coal Fly Ash and Raw or Calcined Natural Pozzolan for Use in Concrete", American Society for Testing and Materials, ASTM International, West Conshohocken, PA, USA, 2003.

[37] T. Hirschi, H. Knauber, M. Lanz, J. Schlumpf, J. Schrabback, C. Spirig and U. Waeber, "Hardened Concrete", Sika Concrete Handbook, Sika Services AG, Switzerland, pp. 102, December 2005.

Publish your books with AIJR publisher-

- Publish with ISBN and DOI.

- Publish Thesis/Dissertation as Monograph.

- Publish Book Monograph.

- Publish Edited Volume/ Book.

- Publish Conference Proceedings

- $\quad$ Retain full copyright of your books.

Submit your manuscript at books.aijr.org

Publish your research article in AIJR journals-

- Online Submission and Tracking

- Peer-Reviewed

- Rapid decision

- Immediate Publication after acceptance

- Articles freely available online

- Retain full copyright of your article.

Submit your article at journals.aijr.in 